\title{
THE FATE OF WATER-SOLUBLE PHOSPHATE APPLIED TO SOME MINERAL SOILS
}

\author{
ARMi KaILA \\ University of Helsinki, Department of Agricultural Chemistry
}

Received January 13, 1965

In a previous paper (9) results were reported on the distribution of applied water-soluble phosphate in the various fractions of inorganic phosphorus in 180 samples of mineral soils. Samples suspended in $\mathrm{KH}_{2} \mathrm{PO}_{4}$-solution in the ratio of 1 to 50 of soil to solution retained, on the average, about one half of the applied 250 $\mathrm{mg} \mathrm{P} / \mathrm{kg}$ of soil during a period of contact of 24 hours. On the average, about 56 per cent of the retained phosphorus was found in the fluoride soluble fraction, and about 40 per cent in the alkali soluble fraction when the treated samples were analysed by the method of CHANG and JACKSON (3) after standing moist for three days since the removal of the phosphate solution by centrifuging. It was emphasized that the results may be significantly different, if the period of contact would be longer, and also, if smaller or larger amounts of phosphate were applied.

In order to get more information about the effect of the rate of the application of the soluble phosphate on the forms in which it will be retained, some further studies were performed. An incubation experiment under the laboratory conditions was carried out, and also the distribution of varying amounts of added phosphate shortly after the application was studied. The results are compared with some data from a couple of field experiments.

\section{Material and methods}

The material of the present study consists of twelve samples chosen to represent mineral soils of a largely varying phosphate sorption capacity and of different patterns of phosphate retention. The samples are listed in Table 1 with some of the characteristics important for the present study. Ten of the samples are from the plough layer of arable lands, the sample 4 is from the surface layer of a virgin soil, and the sample 12 originates from the layer of the depth of 20 to $30 \mathrm{~cm}$ of a 
Table 1. Soil samples

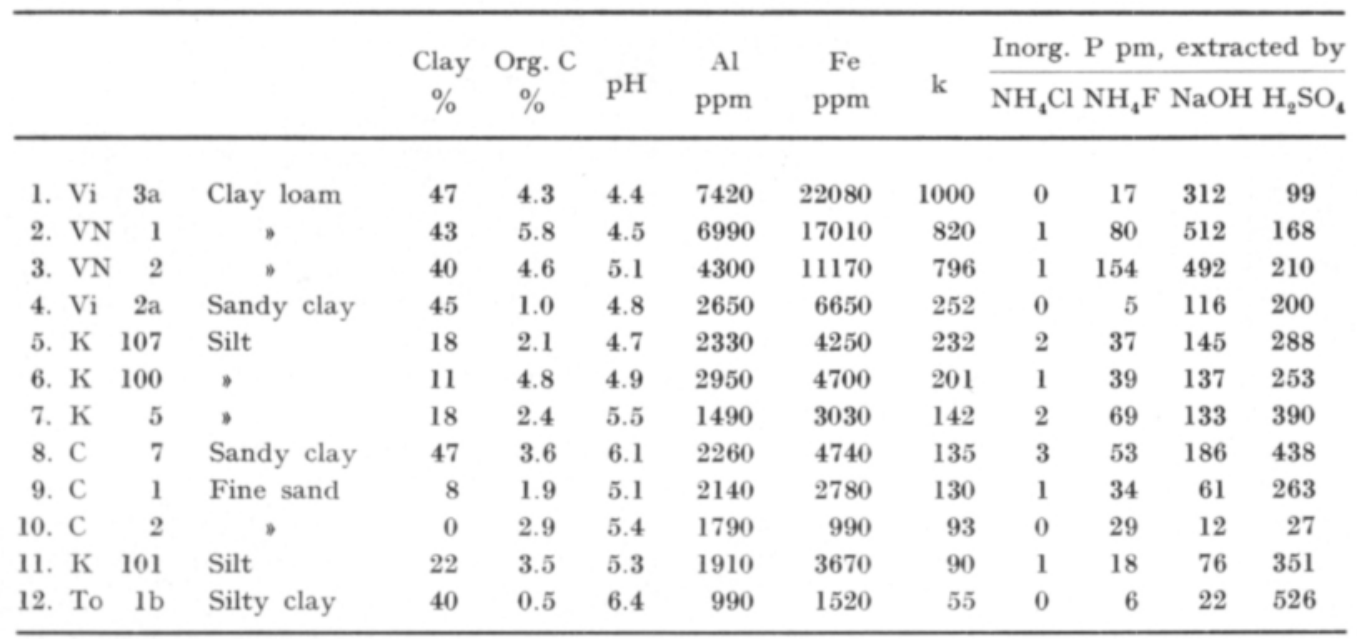

virgin soil. Samples 1 and 2 represent the so-called Litorina soils, postglacial marine sediments characterized by a fairly high acidity and high contents of soluble salts and sesquioxides.

The soil $\mathrm{pH}$ was measured in $1: 2.5$ suspension in $0.01 \mathrm{M} \mathrm{CaCl}_{2}$ by the glass electrode. The content of organic carbon was estimated by the procedure of Walkley, using the iodometric titration, and the content of clay was determined by the common areometer method. Aluminium and iron were extracted by Tamm's acid ammonium oxalate solution. Aluminium was determined by the Aluminon method and iron by the sulfosalicylic acid procedure after the destruction of the organic matter by ignition. The indicator of the inorganic-P-sorption capacity was estimated by a procedure based on the Freundlich adsorption isotherm (cf. 7).

The fractionation of inorganic phosphorus was performed by the method of CHANG and JACKSON (3), instead of the neutral $\mathrm{NH}_{4} \mathrm{~F}$-solution a slightly alkaline extractant was used. The occluded forms were not determined.

The samples are listed in the order of the decreasing values of the indicator of the phosphorus sorption capacity, k. In this material it ranges from 1000 to 55 . The average value of $\mathrm{k}$ in a larger material of our soils was found to be $290 \pm 17$ in sand and fine sand soils, $201 \pm 24$ in loam and silt soils, and $308 \pm 20$ in clay soils (7). It does not appear to be closely connected with the clay content, or with the acidity. On the other hand, the amounts of acid oxalate soluble aluminium and iron seem to be associated with the values of $\mathrm{k}$ also in the present material.

The results of the fractionation of inorganic phosphorus reveal some features typical of our soils (8). The content of the $\mathrm{NH}_{4} \mathrm{Cl}$-soluble phosphorus is very low. An extremely low content of $\mathrm{NH}_{4} \mathrm{~F}$-soluble phosphorus is found in the samples 4 and 12 from the virgin soils, and this fraction is smaller than that soluble in alkali in all the other soils except in the fine sand sample C 2. The relatively high content of alkali-soluble phosphorus characterizes the samples of Litorina soils, numbers 1 and 2. The occurence of a fairly large part of the inorganic phosphorus in the 
other samples as the acid-soluble form, may be attributed to the fact that our soils are rather young, and the weathering processes appear to have only sparingly mobilized the original apatite phosphorus to forms bound by iron and aluminium.

The treatments in the incubation experiment were $0,100,200$, or $500 \mathrm{mg} \mathrm{P} / \mathrm{kg}$ of soil. $100 \mathrm{~g}$ samples

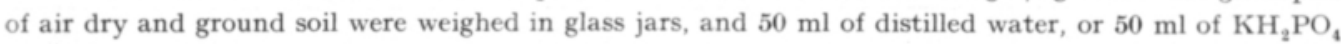
solutions containing 200,400 , or $1000 \mathrm{mg} \mathrm{P} / 1$, respectively, were added. The soils were dried to about the field capacity, mixed well, and incubated under a loose cover for three months at $18-20^{\circ} \mathrm{C}$. The samples were air-dried and ground before analysing.

In order to preparate the material for the study of the distribution of the applied phosphorus immediately after the application, $1 \mathrm{~g}$ samples of air-dry and ground soil were weighed in a centrifuge tube, and $50 \mathrm{ml}$ of distilled water, or solutions of $\mathrm{KH}_{2} \mathrm{PO}_{4}$ containing 2,4 , or $10 \mathrm{mg} \mathrm{P} / 1$, resp., were added. Thus the applications of phosphorus correspond to those in the incubation experiment. In addition, one sample was treated with phosphate solutions corresponding to applications of $1000,2000,5000$, or $10000 \mathrm{mg} \mathrm{P}$ per kilogram of soil. The suspensions were shaken for two hours, centrifuged, and the fractionation of inorganic phosphorus was carried out.

The increase in the phosphorus content of the various fractions in the samples treated with phosphate as compared with the values obtained for the samples treated with distilled water is taken to indicate the accumulation of the applied phosphate. Mineralization of soil organic phosphorus, or microbiological immobilization of inorganic phosphorus is supposed to be equal in all the treatments, and relatively insignificant. In the incubation experiment it was found that the total amount of phosphorus extracted by the fractionation procedure from the samples incubated for three months without any application of phosphate were 0 to $25 \mathrm{ppm}$ higher than those from the original samples.

\section{Results}

The results of the incubation experiment are reported in Table 2. The $\mathrm{pH}$ values in the incubated samples differ from the orginal ones only by -0.3 to $+0.1 \mathrm{pH}$ units. The changes seem to be independent on the treatments. Thus, differences in the acidity of the variously treated samples are not likely to play any significant role in the distribution of the applied phosphorus.

The recovery of the phosphorus is usually somewhat less than 100 per cent of the amount added. There are no reasons to suppose that this deficit would be caused by an accumulation of phosphorus in the occluded forms. It is probable that losses during the fractionation procedure and a possibly heterogeneous distribution of the added phosphorus in spite of the thorough mixing account for the incomplete recovery.

As could be expected, the largest part of the applied soluble phosphate is recovered in the fluoride-soluble and alkali-soluble forms. Only in a few samples it has remained soluble in ammonium chloride to any marked extent. On the other hand, the acid-soluble fractions has also accumulated very little or not at all of the applied soluble phosphate, except in some samples with a fairly high $\mathrm{pH}$ and a low content of iron and aluminium. It is likely that the small increases in this fraction in acid samples may be due to analytical errors.

There are typical differences in the pattern of the distribution of the applied phosphorus between the fluoride-soluble and alkali-soluble forms. The clay loam sample Vi 3a has retained 80 to 90 per cent of the recovered phosphorus in the 
Table 2. Distribution of the applied $\mathrm{P}$ in various fractions in soil samples incubated for three months

\begin{tabular}{|c|c|c|c|c|c|c|c|}
\hline \multirow{2}{*}{ Sample } & \multirow{2}{*}{$\begin{array}{c}\mathrm{P} \\
\text { ppm } \\
\text { applied }\end{array}$} & \multirow{2}{*}{$\mathrm{pH}$} & $\begin{array}{c}\mathrm{P} \\
\mathrm{ppm}\end{array}$ & \multicolumn{4}{|c|}{ Per cent of recovered $P$ extracted by } \\
\hline & & & recovered & $\mathrm{NH}_{4} \mathrm{Cl}$ & $\mathrm{NH}_{4} \mathrm{~F}$ & $\mathrm{NaOH}$ & $\mathrm{H}_{2} \mathrm{SO}_{4}$ \\
\hline \multirow[t]{3}{*}{ 1. Vi $3 \mathrm{a}$} & 100 & 4.5 & 95 & 0 & 11 & 88 & 1 \\
\hline & 200 & 4.5 & 185 & 0 & 15 & 84 & 1 \\
\hline & 500 & 4.5 & 492 & 0 & 17 & 80 & 3 \\
\hline \multirow[t]{3}{*}{ 2. VN 1} & 100 & 4.3 & 102 & 0 & 27 & 73 & 0 \\
\hline & 200 & 4.3 & 199 & 0 & 32 & 68 & 0 \\
\hline & 500 & 4.3 & 483 & 1 & 36 & 63 & 0 \\
\hline \multirow[t]{3}{*}{ 3. VN 2} & 100 & 4.7 & 104 & 0 & 45 & 55 & 0 \\
\hline & 200 & 4.7 & 201 & 0 & 51 & 49 & 0 \\
\hline & 500 & 4.7 & 491 & 2 & 52 & 45 & 1 \\
\hline \multirow[t]{3}{*}{ 4. Vi $2 \mathrm{a}$} & 100 & 4.9 & 83 & $\theta$ & 29 & 71 & 0 \\
\hline & 200 & 4.9 & 172 & 0 & 34 & 66 & 0 \\
\hline & 500 & 5.0 & 461 & 2 & 42 & 54 & 2 \\
\hline \multirow[t]{3}{*}{ 5. K 107} & 100 & 4.4 & 98 & 2 & 52 & 43 & 3 \\
\hline & 200 & 4.4 & 178 & 4 & 59 & 35 & 2 \\
\hline & 500 & 4.4 & 477 & 5 & 63 & 29 & 3 \\
\hline \multirow[t]{3}{*}{ 6. K 100} & 100 & 4.5 & 93 & 3 & 59 & 35 & 3 \\
\hline & 200 & 4.5 & 179 & 4 & 64 & 28 & 4 \\
\hline & 500 & 4.5 & 481 & 6 & 67 & 25 & 2 \\
\hline \multirow[t]{3}{*}{ 7. K 5} & 100 & 5.2 & 104 & 7 & 56 & 36 & 1 \\
\hline & 200 & 5.2 & 204 & 8 & 55 & 32 & 5 \\
\hline & 500 & 5.2 & 489 & 12 & 60 & 25 & 3 \\
\hline \multirow[t]{3}{*}{ 8. C 7} & 100 & 5.8 & 90 & 3 & 45 & 48 & 4 \\
\hline & 200 & 5.8 & 189 & 4 & 40 & 43 & 13 \\
\hline & 500 & 5.8 & 484 & 7 & 48 & 40 & 4 \\
\hline \multirow[t]{3}{*}{ 9. C 1} & 100 & 5.0 & 88 & 1 & 52 & 40 & 7 \\
\hline & 200 & 5.0 & 192 & 3 & 61 & 31 & 5 \\
\hline & 500 & 5.2 & 469 & 3 & 59 & 35 & 3 \\
\hline \multirow[t]{3}{*}{ 10. C 2} & 100 & 5.3 & 90 & 2 & 85 & 12 & 1 \\
\hline & 200 & 5.3 & 179 & 3 & 88 & 8 & 1 \\
\hline & 500 & 5.3 & 486 & 6 & 86 & 8 & 0 \\
\hline \multirow[t]{3}{*}{ 11. K 101} & 100 & 5.0 & 94 & 5 & 48 & 36 & 11 \\
\hline & 200 & 5.1 & 192 & 7 & 53 & 34 & 6 \\
\hline & 500 & 5.0 & 492 & 11 & 58 & 26 & 5 \\
\hline \multirow[t]{3}{*}{ 12. To $1 \mathrm{~b}$} & 100 & 6.5 & 93 & 6 & 47 & 36 & 11 \\
\hline & 200 & 6.5 & 176 & 15 & 51 & 23 & 11 \\
\hline & 500 & 6.3 & 487 & 22 & 54 & 17 & 7 \\
\hline
\end{tabular}


latter fraction supposed to be bound by iron whereas the fine sand sample $\mathrm{C} 2$ has accumulated 85 to 88 per cent of it in the former fraction which is assumed to be mainly connected with aluminium. In the other samples the applied phosphorus appears to have been divided more equally between these fractions. Usually, the fluoride-soluble part is larger, but in the samples 1, 2 and 4 the alkali-soluble fraction dominates.

The most interesting question of this experiment, the effect of the rate of the application on the distribution is answered by these results fairly distinctly. The larger the amount of phosphate applied, the higher part of it may be found in the fluoride soluble form and the less in the alkali-soluble form. Also the part which remains soluble in $\mathrm{NH}_{4} \mathrm{Cl}$ increases with an increase in the application.

When the soil samples were submitted to the fractionation procedure immediately after the treatment with the phosphate solutions, results recorded in Table 3 were obtained. The part of applied phosphorus retained during the contact of two hours tends to decrease from the samples with a high value of $\mathrm{k}$ to those with a low $\mathrm{k}$, although not quite regularly. It is of particular interest to note that the sample $\mathrm{Vi} 3 \mathrm{a}$, with a value of $\mathrm{k}=1000$, is able to retain within two hours the lowest application of phosphate completely, and even about two thirds of the application of 500 $\mathrm{ppm}$. The percentile retention decreases, of course, when the application is increased, but the absolute amounts increase. From the $10000 \mathrm{ppm}$ soluble phosphorus added this sample sorbs $2200 \mathrm{ppm}$. Even in this case more than one half of the retained phosphorus is found in the alkali soluble fraction which fact indicates the dominance of iron in the pattern of phosphorus fixation in this soil. The samples K 5 and K 101, on the other hand have retained only $20 \mathrm{ppm} \mathrm{P}$ or less from the application of 100 ppm, and 16 or 15 per cent from the application of $500 \mathrm{ppm}$.

The figures in Table 3 showing the percentage of the recovered phosphorus in the various fractions differ surprisingly little from the corresponding values in Table 2 for the samples incubated for three months. The part which has been remained soluble in ammonium chloride is slightly higher in the samples analysed immediately after the application of phosphate, but this fraction, apparently, represents in this case only an indefinite portion of the phosphate not sorbed by the soil constituents during the two hours of contact. The percentage of recovered phosphorus in the fluoride-soluble fraction is higher and that in the alkali-soluble fraction correspondingly lower than in the incubated samples, but the differences may be rather small in some samples. Only in few cases, some of the applied phosphorus has been recovered in the acid-soluble form. In accordance with the results obtained for the incubated samples, the part of the applied phosphate found in the fluoridesoluble form tends to increase with an increase in the application whereas the contrary is true in regard to the alkali-soluble form.

The pattern of the retention appears to be characteristic of the soil from the period of contact of two hours to the period of three months. In the sample $\mathrm{Vi} 3 \mathrm{a}$ 79 to 82 per cent of the recovered phosphorus in the unincubated samples was in the alkali-soluble fraction, in the incubated samples the corresponding part was from 80 to 88 per cent. In the sample C 2 , on the other hand, 70 to 80 per cent of the recovered phosphorus was sorbed in the fluoride-soluble form during the two 
Table 3. Distribution of the applied $\mathrm{P}$ in various fractions in soil samples without incubation

\begin{tabular}{|c|c|c|c|c|c|c|}
\hline \multirow[b]{2}{*}{ Sample } & \multirow{2}{*}{$\begin{array}{l}\text { P ppm } \\
\text { applied }\end{array}$} & \multirow{2}{*}{$\begin{array}{l}\text { Per cent } \\
\text { of } \mathrm{P} \\
\text { retained }\end{array}$} & \multicolumn{4}{|c|}{ Per cent of recovered $\mathrm{P}$ extracted by } \\
\hline & & & $\mathrm{NH}_{4} \mathrm{Cl}$ & $\mathrm{NH}_{4} \mathrm{~F}$ & $\mathrm{NaOH}$ & $\mathrm{H}_{2} \mathrm{SO}_{4}$ \\
\hline \multirow[t]{7}{*}{ 1. Vi $3 \mathrm{a}$} & 100 & 100 & 2 & 16 & 82 & 0 \\
\hline & 200 & 75 & 2 & 17 & 81 & 0 \\
\hline & 500 & 67 & 2 & 19 & 79 & 0 \\
\hline & 1000 & 61 & 1 & 22 & 73 & 4 \\
\hline & 2000 & 47 & 2 & 26 & 70 & 3 \\
\hline & 5000 & 31 & 3 & 31 & 64 & 2 \\
\hline & 10000 & 22 & 5 & 35 & 55 & 5 \\
\hline \multirow[t]{3}{*}{ 2. VN 1} & 100 & 82 & 2 & 37 & 61 & 0 \\
\hline & 200 & 69 & 2 & 38 & 60 & 0 \\
\hline & 500 & 58 & 3 & 40 & 57 & 0 \\
\hline \multirow[t]{3}{*}{ 3. VN 2} & 100 & 80 & 3 & 46 & 51 & 0 \\
\hline & 200 & 54 & 2 & 50 & 48 & 0 \\
\hline & 500 & 45 & 3 & 55 & 42 & 0 \\
\hline \multirow[t]{3}{*}{ 4. Vi $2 a$} & 100 & 55 & 2 & 38 & 60 & 0 \\
\hline & 200 & 48 & 3 & 38 & 59 & 0 \\
\hline & 500 & 33 & 3 & 45 & 52 & 0 \\
\hline \multirow[t]{3}{*}{ 5. K 107} & 100 & 57 & 5 & 48 & 47 & 0 \\
\hline & 200 & 39 & 6 & 53 & 41 & 0 \\
\hline & 500 & 26 & 9 & 57 & 34 & 0 \\
\hline \multirow[t]{3}{*}{ 7. $\mathrm{K} 5$} & 100 & 20 & 20 & 65 & 15 & 0 \\
\hline & 200 & 18 & 11 & 64 & 25 & 0 \\
\hline & 500 & 16 & 16 & 59 & 25 & 0 \\
\hline \multirow[t]{3}{*}{ 8. C 7} & 100 & 37 & 8 & 51 & 41 & 0 \\
\hline & 200 & 29 & 8 & 54 & 38 & 0 \\
\hline & 500 & 20 & 8 & 59 & 33 & 0 \\
\hline \multirow[t]{3}{*}{ 9. C 1} & 100 & 28 & 11 & 64 & 25 & 0 \\
\hline & 200 & 25 & 6 & 67 & 27 & 0 \\
\hline & 500 & 16 & 10 & 74 & 16 & 0 \\
\hline \multirow[t]{3}{*}{ 10. C 2} & 100 & 30 & 0 & 70 & 6 & 24 \\
\hline & 200 & 26 & 2 & 77 & 6 & 15 \\
\hline & 500 & 20 & 5 & 80 & 6 & 9 \\
\hline \multirow[t]{3}{*}{ 11. K 101} & 100 & 19 & 6 & 76 & 18 & 0 \\
\hline & 200 & 19 & 7 & 70 & 23 & 0 \\
\hline & 500 & 15 & 13 & 64 & 23 & 0 \\
\hline \multirow[t]{3}{*}{ 12. To $1 \mathrm{~b}$} & 100 & 29 & 4 & 48 & 24 & 24 \\
\hline & 200 & 22 & 5 & 53 & 30 & 12 \\
\hline & 500 & 13 & 12 & 49 & 21 & 18 \\
\hline
\end{tabular}


Table 4. Ratio of the applied $\mathrm{P}$ in the fluoride-soluble fraction to that in the alkali-soluble fraction and the absolute differences in these fractions in the unincubated (a) and incubated (b) samples

\begin{tabular}{|c|c|c|c|c|c|c|c|}
\hline \multirow{2}{*}{ Sample } & \multirow[b]{2}{*}{$\mathrm{Al} / \mathrm{Fe}$} & \multirow[b]{2}{*}{$\mathrm{Al}-\mathrm{P} / \mathrm{Fe}-\mathrm{P}$} & \multirow{2}{*}{$\begin{array}{c}\mathrm{P} \\
\text { ppm } \\
\text { applied }\end{array}$} & \multicolumn{2}{|c|}{ Sorbed ${ }_{A} \mathrm{Al}-\mathrm{P} / \mathrm{Fe}-\mathrm{P}$} & \multicolumn{2}{|c|}{$\mathbf{b}-\mathbf{a}$} \\
\hline & & & & a & $\mathrm{b}$ & $\Rightarrow \mathrm{Al}-\mathrm{P} n$ & $" \mathrm{Fe}-\mathrm{P} n$ \\
\hline \multirow[t]{3}{*}{ 1. Vi $3 \mathrm{a}$} & 0.7 & 0.05 & 100 & 0.2 & 0.1 & -6 & 2 \\
\hline & & & 200 & 0.2 & 0.2 & 2 & 33 \\
\hline & & & 500 & 0.2 & 0.2 & 20 & 129 \\
\hline \multirow[t]{3}{*}{ 2. $\mathrm{VN} 1$} & 0.8 & 0.16 & 100 & 0.6 & 0.4 & -3 & 24 \\
\hline & & & 200 & 0.7 & 0.5 & 12 & 52 \\
\hline & & & 500 & 0.7 & 0.6 & 58 & 139 \\
\hline \multirow[t]{3}{*}{ 3. $\mathrm{VN} 2$} & 0.8 & 0.31 & 100 & 0.9 & 0.8 & 10 & 56 \\
\hline & & & 200 & 1.1 & 1.0 & 49 & 46 \\
\hline & & & 500 & 1.3 & 1.2 & 131 & 126 \\
\hline \multirow[t]{3}{*}{ 4. $\mathrm{Vi} 2 \mathrm{a}$} & 0.8 & 0.04 & 100 & 0.6 & 0.4 & 3 & 26 \\
\hline & & & 200 & 0.6 & 0.6 & 22 & 57 \\
\hline & & & 500 & 0.9 & 0.8 & 120 & 163 \\
\hline \multirow[t]{3}{*}{ 5. $\mathrm{K} \quad 107$} & 1.1 & 0.26 & 100 & 1.0 & 1.2 & 27 & 15 \\
\hline & & & 200 & 1.3 & 1.7 & 64 & 30 \\
\hline & & & 500 & 1.8 & 2.2 & 227 & 94 \\
\hline \multirow[t]{3}{*}{ 7. K 5} & 1.0 & 0.52 & 100 & 4.3 & 1.6 & 45 & 34 \\
\hline & & & 200 & 2.6 & 1.7 & 89 & 56 \\
\hline & & & 500 & 2.4 & 2.4 & 246 & 102 \\
\hline \multirow[t]{3}{*}{ 8. C 7} & 1.0 & 0.28 & 100 & 1.3 & 0.9 & 22 & 28 \\
\hline & & & 200 & 1.5 & 0.9 & 45 & 59 \\
\hline & & & 500 & 1.8 & 1.2 & 173 & 161 \\
\hline \multirow[t]{3}{*}{ 9. C 1} & 1.6 & 0.56 & 100 & 2.6 & 1.3 & 28 & 28 \\
\hline & & & 200 & 2.4 & 2.0 & 83 & 46 \\
\hline & & & 500 & 4.5 & 1.7 & 218 & 151 \\
\hline \multirow[t]{3}{*}{ 10. C 2} & 3.7 & 2.41 & 100 & 10.5 & 6.9 & 56 & 9 \\
\hline & & & 200 & 13.3 & 11.3 & 118 & 11 \\
\hline & & & 500 & 13.2 & 10.4 & 338 & 33 \\
\hline \multirow[t]{3}{*}{ 11. K 101} & 1.1 & 0.24 & 100 & 3.0 & 1.3 & 31 & 31 \\
\hline & & & 200 & 3.0 & 1.5 & 75 & 56 \\
\hline & & & 500 & 2.7 & 2.2 & 237 & 111 \\
\hline \multirow[t]{3}{*}{ 12. To $1 \mathrm{~b}$} & 1.4 & 0.27 & 100 & 2.0 & 1.3 & 30 & 26 \\
\hline & & & 200 & 1.8 & 2.2 & 67 & 27 \\
\hline & & & 500 & 2.3 & 3.1 & 230 & 69 \\
\hline
\end{tabular}


hours of contact, whereas the values found for the incubated samples were 85 to 88 per cent. The patterns of the other soils are less distinct, but almost without an exception the samples which in the incubation experiment had accumulated more applied phosphorus in the alkali-soluble than in the fluoride-soluble form, or vice versa, did so also when the fractionation was performed after two hours of contact. This is particularly noteworthy, since in some soils the immediate retention has been only from 13 to 30 per cent of that in the incubation experiment.

Since in our soils the retention of soluble phosphorus seems to be almost completely depending on the factors determining its extractability by the fluoride or the alkali solutions of the fractionation procedure, a more detailed study of these fractions in the results of the present experiments may be illuminating. Table 4 contains data which show the ratio between the increases in the so-called $n \mathrm{Al}-\mathrm{P} n$, or the fluoride-soluble fraction, and in the ${ }^{\mathrm{F} e} \mathrm{~F}-\mathrm{P} \|$, or the alkali-soluble fraction both in the results obtained immediately and in those from the incubation experiment. Also the ratios of the acid oxalate soluble aluminium to iron (in moles) and the ratios of the fluoride-soluble and alkali-soluble phosphorus in the original samples are recorded. These data show that the distribution of the applied phosphorus in these two fractions in the incubated and unincubated soils is fairly similar in the first four samples. All of them are characterized by a higher increase in the alkali-soluble than in the fluoride-soluble form, at least in connection with the lowest application. This is in accordance with the molar ratio of oxalate-soluble aluminium to iron being less than 1 in these soils. In samples having a higher ratio of $\mathrm{Al} / \mathrm{Fe}$, the applied phosphorus has been accumulated in the fluoride-soluble form in larger amounts than in the alkali-soluble form. Although also in these samples the ratio between the sorbed amounts of $" \mathrm{Al}-\mathrm{P}_{\|}$and ${ } \mathrm{Fe}-\mathrm{P}_{\|}$tends to increase with the rate of application, this seems to be less regular than in the first samples. In these soils, also the ratios in the incubated samples partly appear to be higher than those in the unincubated ones.

It has been claimed (2) that while the newly retained phosphorus is mainly fixed as the aluminium bound form, the amount of the iron bound form will increase in time and usually surpass the other forms. The data in Table 4 showing the difference in the fluoride-soluble phosphorus and in the alkali-soluble phosphorus in the incubated and unincubated samples indicate that this is not always the case. In the iron dominated samples Vi 3a, VN 1, and Vi $2 \mathrm{a}$ the increase in the alkali-soluble fraction during the incubation has been markedly higher than that in the fluoridesoluble fraction. Yet, in most of the other soils the increase in the latter fraction has been equal to, or even significantly higher than that in the iron bound form. In all samples the relative increase in the fluoride-soluble fraction as compared to that in the alkali-soluble fraction tends to be the higher the higher the application of phosphate.

According to these laboratory experiments, the part of the applied phosphate sorbed as the fluoride-soluble form usually seems to be the higher and the part sorbed as the alkali-soluble form the lower the larger the amount of phosphate added. Under the field conditions this pattern may be less distinct, particularly on account of the effect of the uptake of phosphorus by plants, and also because of the less thorough mixing of the fertilizers with the soil. 
which is assumed to be bound mainly by aluminium and its compounds. In such extreme cases the pattern appears to be distinct very soon after the phosphate has come into contact with the soil, and this pattern will in time grow more evident. In most of our soils, however, the distribution of the applied phosphate between the fractions supposed to be bound by aluminium or iron appears to be more equal. This could be proved in a previous work (9) on the basis of a larger material as to the newly retained phosphorus. The present results also indicate that these fractions tend to be of the same order, and usually the part of the fluoride-soluble forms is somewhat higher than that of the alkali-soluble forms. The retention of applied soluble phosphorus by calcium as an apatite-like compound seems to occur in our soils only seldom to any marked degree.

Another tendency revealed by the present results is the relative increase in the fluoride-soluble fraction as compared with the alkali-soluble fraction when the rate of the application of the soluble phosphate increases. This is apparent even in those samples in which the pattern of phosphate retention is dominated by iron. The few data from the field experiments are in accordance with the results of the laboratory studies.

It is likely that in the fractionation procedure used, the ammonium fluoride solution will extract not only aluminium bound phosphorus but also e.g. dicalciumphosphate $(5,6,10$, etc.). The importance of this fraction as a source of phosphorus for plants has been emphasized $(4,11)$. In alkaline soils the uptake of phosphorus has been reported to be correlated with the iron bound form (1). There are no informations of the availability of phosphorus in the various fractions in our soils.

Probably, there are differences even within the same fraction in the intensity of the sorption. It is possible that e.g. the newly retained phosphorus in the fluoridesoluble or alkali-soluble fraction is more easily available for the plants than phosphorus in the same fractions in the samples incubated for three months. If fhe fluoridesoluble fraction would represent phosphorus which the plants are able to utilize more easily than the alkali-soluble phosphorus, the present results would, for their part, explain why a fairly large application of phosphate fertilizers is necessary to secure the phosphorus nutrition of the crops in most of our soils: the part of the applied phosphorus sorbed in the fluoride-soluble forms is the lower the lower the application of fertilizer phosphorus. Attention must be paid to the fact that the lowest amount of phosphorus added in the present laboratory experiments was $100 \mathrm{ppm}$ which corresponds to about 2200 to $2800 \mathrm{~kg}$ superphosphate per hectare. From this addition a slightly higher part was sorbed as the fluoride-soluble form than as the alkali-soluble form. When only about 200 to $400 \mathrm{~kg}$ superphosphate is added per hectare, the part which will be retained as the fluoride-soluble fraction may be markedly lower than that retained in the alkali-soluble fraction.

\section{$S u m m$ ary}

The distribution of applied water-soluble phosphorus in the various fractions of soil inorganic phosphorus was studied in an incubation experiment under the laboratory conditions. Samples of twelve soils were incubated for three months 
at room temperature with the applications of $\mathrm{KH}_{2} \mathrm{PO}_{4}$ in amounts corresponding to 100,200 , or $500 \mathrm{mg} \mathrm{P} / \mathrm{kg}$ of soil. The results of the fractionation showed that in most samples the applied phosphorus could be found almost completely in the fluoridesoluble and alkali-soluble fractions, the part of the former being the higher and that of the latter the lower the higher the rate of the phosphate application. Similar results were obtained also when the fractionation was performed after the samples had been in contact with the phosphate solutions only for two hours. Analyses of samples from two field trials were in accordance with these results.

The soils tended to have a characteristic pattern of phosphate retention which in extreme cases means an almost complete sorption of the applied phosphate either as the fluoride-soluble form or as the alkali-soluble form. In most soils, however, the distribution was more equal. Usually the fluoride-soluble part of the recovered phosphorus tended to be somewhat higher than the alkali-soluble part. This tendency was more distinct in regard to the newly retained phosphorus.

The effect of phosphate fertilizers in our soils is discussed on the basis of the results.

\section{REFERENCES}

(1) Al-Abbas, A. H. \& Barber, S. A. 1964. A soil test for phosphorus based upon fractionation of soil phosphorus. Soil Sci. Soc. Amer. Proc. 28: 218-224.

(2) Chang, S. C. \& С не, W. K. 1961. The fate of soluble phosphate applied to soils. J. Soil Sci. 12: $286-293$.

(3) - - \& JAckson, M. L. 1957. Fractionation of soil phosphorus. Soil Sci. 84: $133-144$.

(4) Hanley, K. 1962. Soil phosphorus forms and their availability to plants. Irish J. Agr. Res. 1: $192-193$.

(5) Kall. A. 1961. Fertilizer phosphorus in some Finnish soils. J. Sci. Agr. Soc. Finland 33: 131 - 139.

(6) - - 1963. Fertilizer phosphorus in various fractions of soil phosphorus. Ibid. $35: 36-46$.

(7) - 1963. Dependence of the phosphate sorption capacity on the aluminium and iron in Finnish soils. Ibid. 35: 165-177.

(8) - 1964. Fractions of inorganic phosphorus in Finnish mineral soils. Ibid. 36: 1-13.

(9) -1 1964. Forms of newly retained phosphorus in mineral soils. Ibid. 36: 65 - 76.

(10) Laverty, J. C. \& McLean, E. O. 1961. Factors affecting yields and uptake of phosphorus by different crops: 3. Soil Sci. 91: 166-171.

(11) MacKenzie, A. F. 1962. Inorganic soil phosphorus fractions of some Ontario soils as studied using isotopic exchange and solubility criteria. Canad. J. Soil Sci. 42: 150.156.

SEL O T U S:

KIVENNÄISMAIHIN LISÄTYN VETEEN LIUKENEVAN FOSFORIN PIDÄTTYMISESTÄ

Armi Kaila

Yliopiston maanviljelyskemian laitos, Pihlajamäki

Kahdentoista kivennäismaan näytteisiin lisättiin 100, 200 tai $500 \mathrm{mg} \mathrm{P} / \mathrm{kg} \mathrm{KH}_{2} \mathrm{PO}_{4}$ :na ja näytteitä muhitettiin kolme kuukautta huoneen lämpötilassa. Toinen näytesarja analysoitiin heti, kun niitä oli kahden tunnin ajan huiskutettu vastaavat fosforin määrät sisältävissä liuoksissa. Fraktioinnin tulokset 
osoittivat, että useimmissa maissa lisätty fosfori oli joutunut miltei kokonaan fluoridiin ja emäkseen liukeneviin fraktioihin. Edellisen osuus oli tavallisesti sitä suurempi ja jälkimmäisen sitä pienempi, mitä enemmän fosforia oli lisätty. Vastaavanlaisia tuloksia saatiin myös analysoimalla eräitten kenttäkokeitten maanäytteitä.

Maat näyttivät edustavan tiettyjä fosforin pidätyksen tyyppejä, joiden äärimmäisyyksinä olivat maat, jotka pidättivät lisätyn fosforin miltei kokonaan joko fluoridiin tai emäkseen liukenevaan muotoon. Useimmissa maissa lisätty fosfori jakautui tasaisemmin näiden fraktioiden kesken. Myös muhitetuissa näytteissä fluoridiin liukeneva osa oli tavallisesti hiukan suurempi kuin emäkseen liukeneva.

Todettiin, että mikäli emäkseen liukeneva fraktio todella edustaisi huomattavasti vaikeammin kasveille käyttökelpoista fosforia kuin fluoridiin liukeneva osa, olisi syytä käyttää etenkin runsaasti rautaa sisältävissä maissa voimakasta fosforilannoitusta satojen fosforin saannin turvaamiseksi. 